\title{
移行期ロシアの労働市場におけるジェンダー問題
}

\author{
藤 原 克 美 \\ (大阪外国語大学)
}

\section{Gender Problems in the Labor Market during the Russian Transition}

\author{
FujIWARA, katsumi \\ Osaka University of Foreign Studies
}

\begin{abstract}
Only few attempts have so far been made at gender approach to the transition economy in Russia. In contrast to the development of sociological gender studies, most of Russian economists simply neglect gender problems and some even deny the existence of the gender gap and inequality of opportunity. This paper critically examines the argument denying the gender gap in Russian labor market.

First of all, the gender disparity in the labor market is reflected not in unemployment rate but in the structure of labor market. Almost 70 percent of workers who had dropped out of employment were women. Many of them seem to have chosen to retire or to stay at home. It is hasty to assume the gender equality in the labor market without considering the reason why these women have left for economically nonactive.

It is an undeniable fact that there exists gender segregation in Russian labor market. The main point of dispute lies how or why gender segregation is generated. Interindustry wage differentials are explained by the fact that average wages in 'feminized' (women's) industries such as light industry, education or health care are relatively low. Under the condition of gender segregation, the widening of interindustry wage differentials are manifest in the widening of wage differentials by sex. On the other hand, the wage differential is caused by the fact that women take relatively lowwage and low-skilled jobs in the branch. Economists denying the existence of the gender gap explain this situation as a result of 'normal' function of market, that is, a result of free choices made by individuals. They argue that women are more tolerant of low-wage jobs because of their position as subsidiary earners in household. However, this explanation already presupposes the dominance of patriarchal ideology, which is one of the typical form of gender discrimination.

In reality, gender segregation is caused by inequalities of opportunity for recruitment and advancement within a company between men and women. Therefore, the differences in job evaluation of workers would not correspond to the differences in real skill level of them.
\end{abstract}

Keywords: gender, labor market, segregation, (in)equality of opportunity 
Thus, it seems reasonable to conclude that in Russian labor market in 90's there were apparent gender gap in both wage and employment. While withdrawal of women from the workplace was strongly affected by the severe depression resulting from the transition, the important factor that made women main victim of depression would be informal inequalities of opportunity for recruitment and advancement. Female-worker's individual decision which concerns joining the workforce was made within the framework of this inequality.

\section{は じめに}

ジェンダー概念は近年, 政治学, 社会学, 経済学など社会科学のさまざまな領域に取り入れ られている。しかし，ロシアの移行経済をジェンダーの視点から分析した研究は，これまでの ところ多くはない。『経済の諸問題』誌が 2000 年 3 月号でジェンダ一問題の特集を組むなど(1), いくらかの関心の高まりも見られるが，全体としてはまだジェンダー研究は端緒的な段階にあ ると言ってよい。

ロシアの経済学者の多くは, ジェンダー問題に無関心である。例えばシュカラタン編集の 『国家の社会政策と家計の生存戦略』の第 8 章「雇用の危機とミクロレベルでのその克服方法」 （チーホノヴァ，ダヴィドヴァ著）には，性差の分析は全く出てこない(2)。ジェンダー格差の 問題に言及している少数の文献も, 格差の存在については否定的である。著名な労働経済学者 であるカペリューシュニコフは，雇用（变失）機会には男女間で全く差がないと論じている ${ }^{(3)}$ 。 また経済研究所労働市場研究センターの報告書は, ジェンダー・セグリゲーション（性別職域 分離）およびそれに伴う賃金格差の存在は認めつつも，それらの格差を「差別」の結果ではな く「正常な」市場機能（すなわち個人の自由な選択）の結果として説明している(4)。

一方，ロシアのジェンダー研究者は，労働市場におけるジェンダー格差の存在を主張してい る。ロシアに拈けるジェンダ一研究は, 歷史的には比較的浅いが, 海外の研究者・諸団体と交 流しながら，すでに一定の成果をあげている。しかし，こうした研究では，上記のジェンダー 格差否定論の存在はあまり意識されていない。ジェンダー研究者からの発信がさほど経済学者 の関心を呼び起こしていないように見えるのはそのためかもしれない。

本稿では，ロシアにおけるジェンダー研究の成果に依拠しつつ，上記のジェンダー格差否定 論を批判的に検討する。経済学的研究とジェンダー研究の「分離」状況を克服し, 移行経済分

(1) Ржаницына Л., Е. Мезенцева Е. ら合計 15 人が 12 本の論文を寄せている。

(2) Тихонова Н. Е., Давыдова Н. М., «Кризис занятости и пути его преодоления на микроуровне», Гсоударственная социальная политика и стратегии выживания домохозяйств, под ред. Шкаратана О. И., ГУ ВШЭ, 2003, стр. 328-369.

(3) Капелюшников Р. И., Российский рынок труда: адаптация без реструктуризации, ГУ ВШЭ, 2001, стр. 51-52.

(4) Институт Экономики РАН, Центр исследований рынка труда, Положение женшин в реформируемой экономике: опыт России, М., 1995. この報告書は1994-1995 年の同研究所の調査にもとづき，モ スコーフスカヤを代表として作成された。1994年のプロジェクトはILO との共同調査で，責任者は チェトベルニーナであった。プロジェクトにはモスクワ大学, 全ロシア世論調査センター, 社会・人 口問題研究所のスタッフも参加しており, もちろんプロジェクトの参加者がすべての点において見解 を一にしている訳でもない。以下の文献も参照。Институт Экономики РАН, Центр исследований рынка труда, Женщины в реформируемой экономике, М., 1995. 
表 1 失業統計：1992-2002 年

\begin{tabular}{|c|c|c|c|c|c|c|c|c|c|c|c|}
\hline & 1992 & 1993 & 1994 & 1995 & 1996 & 1997 & 1998 & 1999 & 2000 & 2001 & 2002 \\
\hline & \multicolumn{11}{|c|}{ 雇用問題にかんする家計調査データ*) } \\
\hline 失業者総数（1000 人） & 3877 & 4305 & 5702 & 6712 & 6732 & 8058 & 8876 & 9070 & 6999 & 6303 & 6153 \\
\hline 女性（1000人） & 1851 & 2025 & 2628 & 3096 & 3070 & 3688 & 4090 & 4313 & 3219 & 2893 & 2831 \\
\hline \multirow[t]{2}{*}{ （パーセント） } & 47.7 & 47.0 & 46.1 & 46.1 & 45.6 & 45.8 & 46.1 & 47.6 & 46.0 & 45.9 & 46.0 \\
\hline & \multicolumn{11}{|c|}{ ロシア連邦労働省データ（年末） } \\
\hline $\begin{array}{l}\text { 国家雇用局登録失業者数 } \\
(1000 \text { 人) }\end{array}$ & 578 & 836 & 1637 & 2327 & 2506 & 1999 & 1929 & 1263 & 1037 & 1123 & 1309 \\
\hline 女性（1000 人） & 417 & 567 & 1052 & 1455 & 1576 & 1278 & 1247 & 880 & 715 & 763 & 897 \\
\hline (パーセント) & 72.2 & 67.9 & 64.2 & 62.5 & 62.9 & 63.9 & 64.6 & 69.7 & 69.0 & 68.0 & 68.5 \\
\hline $\begin{array}{l}\text { 失業者総数に占める登録 } \\
\text { 失業者数（パーセント） }\end{array}$ & 14.9 & 19.4 & 28.7 & 34.7 & 37.2 & 24.8 & 21.7 & 13.9 & 14.8 & 17.8 & 21.3 \\
\hline 男性失業率 & 5.2 & 5.9 & 8.3 & 9.7 & 10.0 & 12.2 & 13.5 & 12.8 & 10.2 & 9.3 & 9.0 \\
\hline 女性失業率 & 5.2 & 5.8 & 7.9 & 9.2 & 9.3 & 11.5 & 12.9 & 12.4 & 9.4 & 8.5 & 8.1 \\
\hline
\end{tabular}

出所 : Госкомстат России, Россия в иифрах 各年版

*) 1992-1995，1997-1998 年は 10 月末，1996 年 3 月末，1999-2002 年は11月末

析にジェンダー視点を内在化することは，移行過程を多角的にとらえるらえで有益であろう。

\section{1 失業と離職}

カペリューシュニコフは『ロシアの労働市場 : 再編なき適応』（2001 年）のなかで，国家統 計委員会が発表する ILO 基準失業者数にもとづいて（表 1)，「ロシアでは失業者の隊列に入る 可能性は，男性も女性も事実上同じ」であり，「『失業の女性化』というしばしば沶目にかかる 主張は十分な根拠を持たない」と結論している。雇用局への登録失業者に占める割合は女性の 方が男性よりも高いが，カペリューシュニコフによれば「女性の方が男性よりも就職に際して 国家雇用局に斡旋を求める傾向があるということを示しているにすぎない。」しかし，なぜそ らであるかは説明していない(5)。彼の考えでは，女性と男性の失業比率がほぼ同じである（実 際には女性のほらがいくらか低い）ことに対する「もっともありうる説明は，女性の伝統的に 高い経済活動」であり，「男性の労働期間をわずかに下回る女性の労働経験の存在が, 彼らの 労㗢市場での地位を摇るが好にている」(6)。このように，社会主義時代に達成された高 い労働参加率ゆえに, 労働市場に打ける女性の地位は, 男性に劣るものではないといらのがカ ペリューシュニコフの主張である。

しかし，ロシアのジェンダー研究者が「失業の女性化」として念頭に置いているのは，失業

（5）登録失業者数と ILO 基準失業者数には大きな隔たりがあり，連邦雇用局はILO 基準失業者の 14-38\% しかカバーしていない。職業翰旋と手当ての支給という雇用局の基本的な役割に大きな限界があった ためである。しかしながら失業者として登録されると医療サービスや児童手当が受けられるため，女 性のほうが雇用局への登録に積極的であった。

(6) Капелюшников, там же. 
表 2 就業者数の推移

\begin{tabular}{|c|c|c|c|c|c|c|c|c|}
\hline & \multicolumn{4}{|c|}{ 男女別就業者数（1000 人） } & \multirow{2}{*}{\multicolumn{2}{|c|}{ 増减（1000 人） }} & \multirow{2}{*}{\multicolumn{2}{|c|}{ 女性の比率 $(\%)$}} \\
\hline & \multicolumn{2}{|c|}{1990 年 } & \multicolumn{2}{|c|}{1998 年 } & & & & \\
\hline & 男性 & 女性 & 男性 & 女性 & 男性 & 女性 & 1990 & 1998 \\
\hline 鉱工業 & 11899 & 10910 & 8719 & 5413 & $\Delta 3180$ & $\Delta 5497$ & 47.8 & 39.3 \\
\hline 農業 & 5933 & 3794 & 5968 & 2756 & 35 & $\Delta 1038$ & 39.0 & 31.6 \\
\hline 林業 & 195 & 43 & 190 & 49 & $\Delta 5$ & 6 & 18.1 & 20.5 \\
\hline 建設 & 6629 & 2391 & 3866 & 1188 & $\Delta 2763$ & $\Delta 1203$ & 26.5 & 23.5 \\
\hline 運輸 & 3700 & 1234 & 2939 & 1044 & $\Delta 761$ & $\Delta 190$ & 25.0 & 26.2 \\
\hline 通信 & 256 & 628 & 331 & 506 & 75 & $\Delta 122$ & 71.0 & 60.0 \\
\hline 商業・給食 & 1203 & 4666 & 3564 & 5693 & 2361 & 1027 & 79.5 & 61.5 \\
\hline 住宅・公共サービス & 1560 & 1657 & 1855 & 1550 & 295 & $\Delta 107$ & 51.5 & 45.5 \\
\hline 保健 & 741 & 3497 & 842 & 3611 & 101 & 114 & 82.5 & 81.1 \\
\hline 教育 & 1303 & 4763 & 1155 & 4764 & $\Delta 148$ & 1 & 78.5 & 80.5 \\
\hline 文化・芸術 & 342 & 823 & 352 & 762 & 10 & $\Delta 61$ & 70.6 & 68.4 \\
\hline 科学 & 1332 & 1472 & 657 & 645 & $\Delta 675$ & $\Delta 827$ & 52.5 & 49.5 \\
\hline 金融・信用 & 40 & 362 & 210 & 524 & 170 & 162 & 90.0 & 71.4 \\
\hline 管理 & 536 & 1066 & 1447 & 1330 & 911 & 264 & 66.5 & 47.9 \\
\hline その他 & 1542 & 808 & 1282 & 430 & $\Delta 260$ & $\Delta 378$ & 34.4 & 25.1 \\
\hline 計 & 37211 & 38114 & 33377 & 30265 & $\Delta 3834$ & $\Delta 7849$ & 50.6 & 47.6 \\
\hline
\end{tabular}

出所 : Госкомстат России, Российский статистический ежегодник 2001, с. 142-143. より作成。

率ではなく就業構造の推移である（表 2)。ロシアでは 1990 年から 98 年の間に 16-72 歳人口 は 4 万人, 労働可能年齢人口は 1 万 6000 人増えたが, 就業者数は 7532 万人から 6364 万人へ と実に 1168 万人減少した。このらち，雇用減の約 $70 \%$ にあたる 785 万人は女性であり，した がって男性 1 人につき女性 2 人以上が離職したことになる(7)。結果として就業者に占める女性 の比率はこの間に 50.6\% から 47.6\% に低下した。カペリューシュニコフはこらした男女間で の（純）離職者数の顕著な相違には全く関心を払っていない。

こらした離職者数の相違が失業率に反映されないのは, 離職した女性の多くが新たな求職活 動を行うことなく（あるいはそれを断念して）労働市場から「退出」したためである。女性の 労働市場からの退出を促した一つの要因として, 女性は男性よりも5 年早く55 歳から年金を 受給できることが指摘されている(8)。また, 制度の利用自体が限られてはいたが，早期退職年 金受給者の多くも女性であった ${ }^{(9)}$ 。このような年金制度は, 中高年の労働者の労働供給行動に 少なからず影響したと考えられる。

(7) ただし，統計では男女別の入職・離職の数字は示されていないので，ここでいう「離職者数」は入職 者数を差し引いたネットの概念である。

(8) Токсанбаева М., «О социальной уязвимости женщин», Вопросы экономики, 2000, № 3, стр. 137-143.

(9) 1993 年には失業者に占める早期退職年金受給者の割合は $6.5 \%$ ，そのらち女性は $74 \%$ であった。 
表 3 家計の一人あたり所得による主婦の分布（\%)

\begin{tabular}{|l|c|c|c|}
\hline & 低所得層 & 中所得層 & 高所得層 \\
\hline 社会・経済人口問題研究所 1993 年 & 27.3 & 41.4 & 31.2 \\
\hline 経済研究所 1994 年 & 40.9 & 35.2 & 23.9 \\
\hline
\end{tabular}

出所 : Рощин, С.Ю., Занятость женщин в переходной экономике России, ТЕИС, 1996, стр. 106.

表 4 一人あたり実質貨幣所得（1991=100）

\begin{tabular}{|c|c|c|c|c|c|}
\hline 1991 & 1992 & 1993 & 1994 & 1995 & 1996 \\
\hline 100 & 52 & 60 & 67 & 58 & 58 \\
\hline
\end{tabular}

出所 : Госкомстат России, Россия в иифрах 1997, стр. 50. より作成。

さらに，労働市場から退出した女性労働者の一部は専業主婦となった。表 3 のように調査に よって開きがあるものの, 専業主婦は, 夫の高い給与に裏付けされた高所得者層と, 労働市場 の厳しさを示唆する低所得者層という質的に異なる層に分布している。トクサンバエバは, 地 方の主婦の一部は事実上「隠れた失業者」であることは認めながらも, 企業家の出現によって 可能となった豊かな層の存在を強調する ${ }^{(10)}$ 。しかし，体制転換後の数年間には実質所得の 3040\% もの減少が生じたことを考えると（表 4), 多くの家庭では女性が主体的に主婦になる経 済的余裕があったとは思われない。シルバーマンニヤノウィッチもこの点を重視して, 主婦化 の多くは, 社会的労働からの「強制的解放」といら性格の強いものであったと主張してい る(11)。

このように，離職しながら失業統計に現れなかった女性のすべてが年金生活への移行と専業 主婦化によって説明できるわけではないが，これらの女性がどのような要因によって労㗢市場 から退出したのかの分析を抜きにして，労働市場における男女の平等を語るのは性急であろ $\zeta^{(12)}$ 。

$$
2 \text { ジェンダー・セグリゲーション }
$$

ソ連時代には比較的小さいとされてきた男女の賃金格差は体制転換後に拡大し，1998 年時

早期退職年金受給者はその後さらに低下し 99 年には $0.7 \%$ となっている。Четвернина Т., «Пожилые работники на российском рынке труда: уязвимость положения и формы дискриминации», Гендерное равенство: поиски решения старых проблем, МОТ, 2003, стр. 123.

(10) Токсанбаева М., «Женщины в составе экономически активного населения», Женщины в реформируемой экономике, М., 1995. стр. 31-32. ここで引用されている資料では 1993 年に低所得者層が 15.3\%, 高所得者層が $32.6 \%$ であった。

(11) Silverman B, and M. Yanowitch, New Rich, New Poor, New Russia, M.E. Sharpe, Armonk, 2000, p. 74. 専業 主婦のもう一つの特徵に, 育児中の女性の比率の高さがある。シルバーマン＝ヤノウィッチは女性の 経済活動からの退出のもら一つの要因として育児サービスの低下をあげている。

(12) 直接比較することはできないが，1990-1999 年にかけて女性の就業者数は 890 万人の減少，1999年 11 月末現在で 15-72才人口中, 女性失業者は 428 万人, 専業主婦は 307 万人であった（いずれも国家統 計委員会データより計算)。 
表 5 男女の賃金格差と部門間格差

\begin{tabular}{|c|c|c|c|c|c|c|}
\hline \multirow{2}{*}{\multicolumn{2}{|c|}{ 経済部門 }} & \multicolumn{2}{|c|}{$\begin{array}{l}\text { 平均月給（ルーブ } \\
\text { ル）（1998 年） }\end{array}$} & \multirow{2}{*}{$\begin{array}{c}\text { 女性賃金の男性貢 } \\
\text { 金に対する比率 } \\
(\%)\end{array}$} & \multirow{2}{*}{$\begin{array}{c}\text { 部門賃金の経済全体の } \\
\text { 平均貢金に対する比率 } \\
(\%)\end{array}$} & \multirow{2}{*}{$\begin{array}{c}\text { 就業者に占め } \\
\text { る女性の比率 } \\
(\%)\end{array}$} \\
\hline & & 女性 & 男性 & & & \\
\hline \multicolumn{2}{|c|}{ 経済全体 } & 885 & 1258 & 70 & 100 & 48 \\
\hline \multirow{9}{*}{$\begin{array}{l}\text { 鉱 } \\
\text { 工 } \\
\text { 業 }\end{array}$} & 電力 & 1766 & 2200 & 80 & 203 & \multirow{9}{*}{38} \\
\hline & 燃料 & 2022 & 2794 & 72 & 237 & \\
\hline & 鉄鋼 & 1078 & 1562 & 69 & 136 & \\
\hline & 非鉄金属 & 1673 & 2565 & 65 & 219 & \\
\hline & 機械 & 764 & 1042 & 73 & 89 & \\
\hline & 木材・パルプ & 862 & 968 & 89 & 84 & \\
\hline & 建設資材 & 899 & 1160 & 78 & 101 & \\
\hline & 軽工業 & 532 & 649 & 82 & 51 & \\
\hline & 食品 & 1169 & 1398 & 84 & 116 & \\
\hline \multicolumn{2}{|c|}{ 農業* } & 574 & 650 & 88 & 50 & 32 \\
\hline \multicolumn{2}{|c|}{ 建設 } & 1257 & 1583 & 79 & 126 & 21 \\
\hline \multicolumn{2}{|c|}{ 運輸 } & 1286 & 1664 & 77 & 156 & 24 \\
\hline \multicolumn{2}{|c|}{ 通信 } & 1269 & 1804 & 70 & 124 & 26 \\
\hline \multicolumn{2}{|c|}{ 商業・給食 } & 941 & 1284 & 73 & 76 & 60 \\
\hline \multicolumn{2}{|c|}{ 住宅公共サービス } & 1009 & 1297 & 78 & 102 & 62 \\
\hline \multicolumn{2}{|c|}{ 保健・体育・社会保障 } & 684 & 871 & 79 & 74 & 46 \\
\hline \multicolumn{2}{|c|}{ 教育 } & 624 & 752 & 83 & 65 & 81 \\
\hline \multicolumn{2}{|c|}{ 文化・芸術 } & 613 & 757 & 81 & 61 & 80 \\
\hline \multicolumn{2}{|c|}{ 科学・科学サービス } & 882 & 1192 & 74 & 77 & 68 \\
\hline \multicolumn{2}{|c|}{ 金融・信用・保険 } & 1986 & 2565 & 77 & 163 & 50 \\
\hline \multicolumn{2}{|c|}{ 管理機関 } & 1590 & 1901 & 84 & 107 & 71 \\
\hline
\end{tabular}

出所 : Белоконная Л., «Гендерная статистика в России», Вопросы экономики, 2000 № 3, стр. 118. Госкомстат России, Сочиальное положение и уровень жизни населения России 2003, стр. 85. より作成。 *農業のみ 99 年の数字

点での女性の平均賃金は男性の 70\% である（2001 年には 63\%）(13)。女性の雇用比率は軽工業 や教育など相対的に賃金の低い部門で特に高いが，賃金格差そのものは，全ての産業で存在す る（表 5)。このことから，女性は同一部門内でも，相対的に賃金の低い職種・地位について いることがわかる(14)。

経済研究所労働市場研究センターの報告は，こらしたジェンダー・セグリゲーションの存在

(13) 全ロシア世論調査センターの数字ではさらに低く女性の貨金は男性の 50-55\% である。Хоткина 3. A, «Гендерный подход к анализу труда и занятости», Гендерный калейдоскоп, Московский центр гендерных исследований РАН, Академия, 2002 стр. 364.

(14) 職種・地位を考慮した場合，男女賃金格差は数パーセントから十数パーセント程度で，それほぞ ノ 
を事実として認めつつ，「これらの労働と賃金の分断を差別と考えるべきだろらか，女性はそ れ（低兵金または魅力の少ない職種一引用者）よりもクレーン操者やガス溶接工，タクシー運 転手などの男性の仕事に就くことのほうを常に選ぶだろらか」(15) と問いかける。同報告によ れば, 「募集と企業内昇進…は男女でほぼ等しい」(16)。それゆえ, 労働市場に抢ける性的な違 いは女性自身の主体的な選択の結果であり，それが差別によって生じたと考える根拠はないと いうのである。

この見解を検討する前に，セグリゲーションの実態についてもら少し詳しく見ておこう。ロ シアで一般に男性の仕事とされるのは, 林業, 運輸, 建設で, 反対に「女性化」が進んでいる のは教育, 文化・芸術, 保健・体育・社会保障などである。鉱工業, 農業, 科学, 住宅・公共 サービスは混合的な部門である。鉱工業のなかでは, 電力, 燃料, 鉄鋼, 非鉄金属は男性が多 く, 軽工業や食品は女性の比重が高かった。機械工業は混合部門とされている(17)。

職域の分離は, ソ連時代から, 重工業や鉱業など政府が重視する産業に男性が集中し, 軽工 業, 食品, 教育, 保健などで女性の割合が高いという形で存在している( ${ }^{(18)}$ 。移行期には従来 女性が 80-90\% を占めていた商業・金融分野で女性の比重の低下がみられるものの，基本的な 傾向はそれほど変わっていない。

賃金は，ソ連時代は「賃率表（タリフ）」に基づいて国家によって管理され，この賃率表は， サービス業よりも工業，また工業の中では重工業・鉱業に相対的に高い賃金を定めていた。し かし市場移行後の各部門の賃金は，それぞれの部門の市場動向（および対応する労働市場の動 向）に左右されるようになり，かつての賃率表では 2 倍程度であった最低賃金と最高賃金の開 きは, 1998 年には平均の $1 / 2$ から 2.5 倍まで, 約 5 倍に拡大した。特に, 就業者に占める女性 の比率がきわめて高い軽工業では, 1995 年までに生産が 90 年の 2 割以下にまで落ち込んだこ とにより, 経済全体を 100 とする相対的な賃金水準は 1991 年から 1999 年にかけて 105 から 53 へ急落した ${ }^{(19)}$ 。ジェンダー・セグリゲーションのもとでは，こらした部門間賃金格差の 全般的な拡大は，男女間の賃金格差の拡大として現れることになる。

市場移行後の就業者数の変化の男女差はすでに前節の表 2 で見た通りである。就業者に占め る女性の比率の低下は, 1990 年の時点で就業者の約 3 割が従事していた鉱工業において, 男 性の 320 万人に対してその 1.7 倍にあたる 550 万人もの減少が生じたことの影響が大きい。ま た, 農業, 通信, 住宅・公共サービス, 文化・芸術の諸部門では, 女性就業者は減少したのに 対して, 男性の就業者はかえって増加している（特に農業では, 男性は 3 万 5 千人増加してい るのに対して，女性の減少は 104 万人に達する)。商業・金融などソ連時代に遅れていたサー ビス分野では男性，女性ともに就業者が増加しているが，体制転換前には女性が 8 割から 9 割

$\nearrow$ 大きくはない。Рощин С. Ю., Занятость женщин в переходной экономике России, ТЕИС, 1996, стр. 37.

(15) Институт Экономики, Центр исследований рынка труда, там же, стр. 2-3.

(16) Там же.

(17) Чекорина Н., «Женщины и социальная политика в условиях рыночного реформирования», Гендер и экономика: мировой опыт и экспертиза Росийской практики, под ред. Мезенцевой Е. Б., Русская панорама, 2002.

(18) 大津定美氏によると, 女性の分野は軽工業・食品工業・機械工業で, これらの分野は夜勤・深夜勤比 率が低いので労働者にとって入りやすかったという。大津定美『現代り連の労働市場』日本評論社, 1988 年, 66 ページ。

(19) Чекорина Н., там же, стр. 173. 女性の多い軽工業の賃金水準が体制転換直前の時点でほぼ平均並みで あったのは，それが工業の一部門であったためであろう。 
表 6 男女の技能格差

\begin{tabular}{|l|c|c|c|}
\hline \multicolumn{4}{|c|}{ 労動者・職員の職業・技能による男女比（1993 年） } \\
\hline & \multicolumn{2}{|c|}{ 男女比 } & $\begin{array}{c}\text { 非熟練ブルーカラー労働 } \\
\text { 者との賁金差 }\end{array}$ \\
\hline 悱熟練サービス職 & 30.9 & 69.1 & 60 \\
\hline 熟練サービス職 & 21.2 & 78.9 & 111 \\
\hline 非熟練ブルーカラー & 61.1 & 38.9 & 100 \\
\hline 半熟練ブルーカラー & 64.9 & 35.1 & 132 \\
\hline 熟練ブルーカラー & 85.9 & 14.1 & 152 \\
\hline 半熟練ホワイトカラー & 8.5 & 91.5 & 86 \\
\hline 半熟練専門家 & 28.0 & 72.0 & 104 \\
\hline 熟練専門家 & 39.4 & 60.6 & 140 \\
\hline 下級・中級管理者 & 55.3 & 44.7 & 156 \\
\hline 高級管理者 & 70.3 & 29.7 & 432 \\
\hline 新市場就業者 & 81.9 & 18.1 & 340 \\
\hline
\end{tabular}

出所 : Silverman B, and M. Yanowitch, New Rich, New Poor, New Russia, M.E. Sharpe, Armonk, 2000, p. 72. 原典は Институт Экономики РАН, Центр исследований рынка труда, Положение женщин в реформируемой экономике: опыт России, М., 1995, стр. 17, 50.

を占めていたこれらの分野でも男性の増加が目立っている。わずかに教育と林業で男性の就業 者が减少し女性の就業者が増加しているが，前者は低賃金で，後者は過酷な労働条件で際立っ ている部門であり (20)，これらの部門における女性比率の上昇を，労働市場において女性が男 性よりも優位を示した事例とみることは難しい。

軽工業ではこの期間に就業者は 228 万人から 86 万人へと 142 万人も减少した。残念ながら 鉱工業を部門別に分割した男女別雇用統計は得られなかったが，軽工業における離職者の大多 数が女性であったことは間違いない。とはいえ，軽工業における就業者数の減少は全体の $12.1 \%$ にすぎず，鉱工業あるいは経済全体での女性就業者数の大規模な减少は，体制転換の打 撃が「女性化された産業」に集中したことだけでは説明できない(21)。この点で興味深いのは, ホートキナが 1993-94 年にイヴァノヴォ州で行った調査結果である。それによれば，「女性化」 の進んだ繊維企業のみならず，女性の雇用が半数以下であった機械部門でも，経営上の理由に よって解雇を予告された者の氏名を記載した「解雇者リスト」(список высвобождения) ${ }^{(22)}$ は女性ばかりであった ${ }^{(23)}$ 。したがって，人員削减の際には多くの部門で，部門内の女性比率

(20) 林業の貢金データは得られなかった。木材加工では有害な仕事に就いている女性のほらが男性より多 い。 Госкомстат России, Женщины и мужчины России 2002, стр. 109.

(21) 農業の減少については別個の検討が必要であろら。

(22) 1987 年の国有企業法で認められた余剩人員の削減には увольнение ではなくвысвобождение が用い られた。稲子恒夫『政治法律ロシア語辞典』ナウカ, 64 ページ。

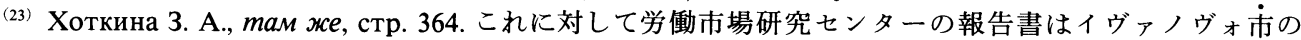
1993 年の雇用局データを利用し，解雇者に占める女性の比率は $50 \%$, 自己都合退職では $48 \%$ で 
の高低に関わりなく，女性がまず対象とされた可能性がある(24)。 セグリゲーションは，部門レベルに扔いてだけでなく，部門内に扔いても，技能の等級の格 差といら形で存在する。一般に高い等級では男性の比重が高く，低い等級では女性の比重が高 い。生産現場では 1-6の等級に分けられるが, 80 年代末から 90 年代初頭には 2-3 等級の差が あった ${ }^{(25)}$ 。また，1993 年のより包括的な分布をみても，高技能の職種ほど男性の比重が高い ことがわかる（表 6)。表 5 で見たよらな部門内の賃金格差は，この技能資格の格差を反映し ていると考えることができる。

\section{3 セグリゲーションの背景}

ジェンダー研究者は，労働市場に打ける女性の「競争力の低さ」が低賃金や高い雇用垡失確 率に反映するものであることを否定しない。女性が家事・育児の大部分を負担するといら状況 を前提にするならば，女性の労働は時間や場所に関してょり限定的にならざるをえないし，出 産と育児のプロセスは，母性保護のコストと勤務の中断の面で男性との競争に颃いて女性を不 利にする。また，体力と意識のかなりの部分を家事（育児・介護を含む）に割くこと自体が， 企業には「仕事に対する心構えが足りない」と映ることもあるだろう。技能資格の格差につい ては前節で見たとおりである（ただし，後段で見るよらに，技能資格は真の技能評価を反映す るものであるとは限らない)。さらにこらした要因によって企業がはじめから女性の労働を相 対的に低く評価するならば，女性の側の労働意欲も減退せざるをえない。

ジェンダー・ギャップ否定論者とジェンダー研究者の主要な争点は, 脑シダー・市ゔリ

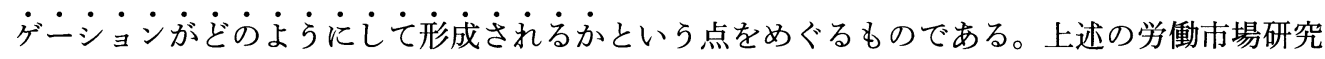
センターの報告では，多くの女性が低賃金の部門・職種を選択するのは，平均的な家計では， 「女性は二次的な労働者である」ためである。すなわち，「女性の賃金は主たる労働者の賃金と 比較して副次的な性格を持っている」ため, 男性と異なり, 自分の技能と比べても相対的に低 い技能レベルで「低賃金の職も受け入れやすい」といらわけである(26)。

女性の賃金が家計において「副次的である」といらことが，金額的な意味で言われているの であれば，上の説明は，女性の賃金の低さをそれ自身によって説明すること，したがって結局 何も説明していないことに等しい。「副次的である」という表現が質的な意味で言われている

】ったとして，このような見解を否定している。Институт Экономики, Центр исследований рынка труда, там же, стр. 11. しかしながら，雇用局で記録される失業理由は，必ずしも企業の雇用・解雇 の行動を反映するものではない。そこで指摘されているように，イヴァノヴォ市は強制的な休暇が広 くみられた地域でもある。

(24) ペレストロイカ期の雇用放出のターゲットも女性，障害者，老齢者であった。塩川伸明『ソヴェト社 会政策史研究』東京大学出版会, 1991 年, 第 11 章。

(25) Мезенцева Е. Б., «Женщина на промышленном производстве: опыт анализа трудовых биографии», Женщина в меняюшемся мире, под ред. Римашевская, Н. М. и др., Наука, 1992, стр. 76.

(26) Институт Экономики, Центр исследований рынка труда, там же, стр. 5-6. 以下の文献ではより明 確に次のように述べられている。「(賃金) 格差は, 労働市場における女性差別というょりも，女性の 社会的役割, すなわち育児と家事負担によってもたらされる。働く女性は家庭に捻いてはしばしば二 次的な労働者であり，したがって，彼らの貨金は主たる労働者の貨金と比較して補足的性格を帯びて いる。このことが，女性の平均賃金の男性平均賃金からの長期にわたる堅固な乘離の主たる原因とも なっている」 Токсанбаева М., «Женщины в составе экономически активного населения», Женщины в реформируемой экономике, Институт Экономики, Центр исследований рынка труда, 1995. стр. 34. 
表 7 就業者・失業者の教育水準（1998 年）

\begin{tabular}{|l|r|r|r|r|r|r|}
\hline & \multicolumn{3}{|c|}{ 就業者 } & \multicolumn{3}{c|}{ 失業者 } \\
\hline & 全体 & 男性 & 女性 & 全体 & 男性 & 女性 \\
\hline 高等専門教育 & 20.7 & 18.9 & 22.6 & 10.3 & 9.4 & 11.2 \\
\hline 高等専門教育 (中途) & 1.9 & 1.9 & 1.9 & 2.4 & 2.4 & 2.5 \\
\hline 中等専門教育 & 33.5 & 29 & 38.4 & 28.2 & 24.0 & 33.0 \\
\hline 中等一般教育 & 32.8 & 36.7 & 28.5 & 41.8 & 43.5 & 39.9 \\
\hline 初等一般教育 & 9.3 & 11.3 & 7.2 & 14.7 & 17.5 & 11.3 \\
\hline 初等一般教育未了 & 1.9 & 2.3 & 1.4 & 2.7 & 3.2 & 2.1 \\
\hline
\end{tabular}

出所 : Госкомстат России, Социальное положение и уровень жизни населения России 2003, стр. 87,91 .

のであれば，それは「男性＝扶養者」という伝統的な家父長制的観念がロシア社会において支 配的であることを前提している点で, 実質的にジェンダー・ギャップの一形態の存在を認めて いる。「男性＝扶養者」「女性＝被扶養者」という観念のもとでの選択を「自由な個人の選択」 と言い切るには，かなりの大胆さが必要であろう。

な拉，最近では「男性＝扶養者」の観念への支持はわずかながら低下しつつあるといら報 告(27) や，生計費に占める女性の収入の比率が男性を上回っているといらアンケート結果(28) も ある。さらに，多くの社会学的調査が示すように，実際には配偶者の収入に頼ることができな い女性も少なくない。女性の低賃金をもっぱら女性の賃金の家計補助的役割から説明しょうと する労働市場研究センターの議論は，こうした点からも一面性を免れない。

さらに，昇進について男女差がないといら同センタ一の主張に反して，学歴と等級の間には 明らかに隔たりがある。15 歳以上の国民の高等教育修了者の比重は, 2001 年にようやく女性 が男性を上回ったところだが（それぞれ 1000 人中 144 人，142 人）, 教育水準の男女格差は特 に高路者層においてみられ，就業者の教育水準ではむしろ女性が男性を上回っている。特に， 高等専門教育および中等専門教育を修了した就業者の比率はいずれも女性の方が男性より高 い。また失業者についてみても同様の傾向がある（表 7)。

1991 年に行われたカマズ自動車工場の調査は, 技能と教育水準の関係を端的に表している （表 8) ${ }^{(29)}$ 。平均技能等級は, 男性は 4.38, 女性は 2.43 で, 約 2 等級の格差がある。一方教育水 準をみると，特に高等教育の資格を持つ女性の割合は $17.2 \%$ で，男性の $13.0 \%$ より高い。し たがって，技能等級は教育水準を反映したものとは言えない。

もちろん, 就業後の職業訓練によっても技能は開発される。しかし, 同じカマズ工場の調査 では，一年間に職業訓練を受けた女性はわずかに $3.7 \%$ であり，男性の $27.1 \%$ を大きく下回 る。さらに, 職業訓練受講後, 男性は自動的に等級が上がるのに対して, 多くの女性の等級に

(27) Хоткина 3. А., там же, стр. 368.

(28) Горшков М. К., Н. Е. Тихонова, Женщина Новой России: Какая она? Как живет? К чему стремитcя? РОССПЭН, 2002, стр. 24.

(29) 以下，カマズ自動車工場のデータは次の資料を参照。Кобзева, Е. В., «Результаты социологического обследования работниц производственного объединения КАМАЗ», Женшина в меняющемся мире, под ред. Римашевская, Н. М. и др., Наука, 1992, с. 64-65. 
表 8 カマズ自動車工場に打ける技能分布と学歷分布

\begin{tabular}{|l|r|r||r|r|r|}
\hline \multicolumn{3}{|c|}{ 技能等級 $(\%)$} & \multicolumn{3}{|c|}{ 教育水準 $(\%)$} \\
\hline 等級 & 男性 & 女性 & 教育 & 男性 & 女性 \\
\hline 等級なし & 16.8 & 17.4 & 中等教育末了 & 5.8 & 2.6 \\
\hline 1-2 等級 & 4.9 & 21.4 & 中等教育 (技術) & 70.5 & 65.4 \\
\hline 3 等級 & 20.0 & 40.0 & 中等専門教育 & 10.7 & 14.8 \\
\hline 4 等級 & 27.1 & 17.6 & 高等教育 & 13.0 & 17.2 \\
\hline 5-6 等級 & 31.2 & 3.6 & \multicolumn{3}{|c}{} \\
\hline
\end{tabular}

出所 : Кобзева, Е. В., «Результаты социологического обследования работниц производственного объединения КАМАЗ», Женщина в меняющемся мире, под ред. Римашевская, Н. М. и др., Наука, 1992, с. 64-65.

は変化がないことから，昇進には明確な男女格差が存在していたと考えられる（2/3の女性は 結婚後等級が上がっていない)。女性自身が家事負担その他の事情で職業訓練を受けることを 望まないといら要因もあるかもしれないが，それとともに，昇進機会の制限が女性の職業技術 向上の熱意をそぐ作用をもつことを見落とすべきではない。

労働力の募集については，求人の際に性別を特定することが慣行化してきているといら指摘 がある ${ }^{(30)}$ 。このよらに採用および昇進機会が男女間で非対称であることを考えるなら，技能 等級の格差は個人の真の能力差に対応するものとは言い難い。先のカマズ自動車工場の機械組 立工の場合，同一の仕事（ポストではない）で，男性と女性の賃金には 55 ルーブルの格差が あった。

ところで，もし技能等級（および貨金）の低い女性労働者の実際の職業的能力が技能等級 （および貨金）の高い男性労働者と同等以上であるとすれば，従業員の削减に際しては，職能 との関係で貨金が相対的に高い男性の労働者を放出する方がより大きなコスト削减効果が得ら れるはずである。ところが，実際には，すでに見たように，多くの産業では女性の離職者の方 が多い。この点に関する説明としてまず考えられるのは，すでに触れた女性の出産・育児に伴 ら企業の負担である。出産・育児に関する手当は，制度上は納税時に控除されて企業の負担に ならないことになってはいるが，実際には多くの企業は女性労働者の出産・育児に伴う休暇や 労働時間の制限を嫌い，しばしば法律に違反して出産・育児中の女性を解雇している(31)。し かし，この要因は，中高年の女性労働者にはあてはまらない（女性失業者の $1 / 3$ 以上は 40 歳 以上である)。したがって, 女性の解雇に際しては, 経営者自身が労働者個人の能力の評価を 反映しないジェンダー意識にとらわれている可能性がある ${ }^{(32)}$ 。

(30) Рощин С. Ю., там же, стр. 40. 彼によると, 求人数としては, 男性限定の募集が女性限定のものより 多いわけではないが，このような性別の特定はジェンダー・セグリゲーションを強化する。制度的に も, 特定の職種で女性の参入の制限がある（ソ連時代には母性保護の観点から $1 / 5$ のポストで女性の 就業が禁じられていた)。

(31) 正確な納税が制度的に前提とされている点にも留意すべきである。また，不当な解雇については労働 者の無知という要因も大きい。Воронина О. А., Феминизм и гендерное равенство, УРСС, 2004, стр. 293-294.

(32) もちろんこのような意識はロシアに限られたものではない。 
以上に見たように，移行期のロシアでは雇用と昇進の機会は男女間で平等であったという主 張は，十分な根拠をもつものではない。90 年代のロシアの労㗢市場には，賃金の面でも，ま た雇用の面でも明確なジェンダー・ギャップが存在した（また現在も存在している）。女性の 低兵金と職場からの締め出しは体制転換に伴ら不況の影響によるところも大きいとはいえ，不 況の痛みがより大きく女性にふりかかった根本的な要因は, 雇用と昇進に打けるインフォーマ ルな形での機会の不平等に求めるべきである。労働市場をめぐる労働者の個人的選択は, この 不平等な枠組みの中で，またその強い影響のもとで行われた。こうした機会の不平等は，潜在 的に等しい労働生産性を持つ労働者が性の違いのみを理由として異なる取り扱いを受けるとい ら意味で,「男女差別」と呼ぶことができる。

日本のロシア経済研究者やジェンダー研究者のなかには, ロシアの労働市場におけるジェン ダー・ギャップの存在はごく「当然」のことであり, 今さら確認するまでもないと考える人も いるかもしれない。しかし，現在のロシアの経済学界では，冒頭で紹介したよらに，格差や機 会の不平等の存在を端的に否定するかなり乱暴な議論が有力な経済学者や研究機関によって行 われているという状況にあり，特定のジェンダー研究者を除けば，ジェンダー的視点はきわめ て希薄である。この点については, ソ連時代にはともかくも男女平等が澾成されたという意識 の影響もあるだろう。母性保護を例外とする法律上の男女の平等な取り扱いの面でソ連の立法 が先進的であったこと，またり連に怙いて女性の高い労働参加率が実現したことは確かであ り，それらを「成果」として肯定的に見ることは誤りではない。しかし，旧ソ連を含む多くの 国々の経験は，法的な平等や労働市場への高い参加率は，それ自体としては，家父長制的な意 識を含むジェンダー・ギャップの解消をもたらすものではないことを示している。

ロシアにおけるジェンダー問題への関心の乏しさは, 研究にバィアスをもたらすと同時に, 統計調査のあり方にも様々な制約を課している。ジェンダー視点を取り入れた統計データは量 が少ない上に，遡及できる年次もごく短い(33)。移行経済の分析にジェンダー視点を取り入れ ることは, 統計資料の豊富化という点でも，現実のより多面的な理解に寄与するであろう。

（本論文は複数レフェリーの審査を経て編集委員会が採択したものである。）

(33) 統計資料集『ロシアの女と男』はこれまで 2000 年と 2002 年に発行されている。それ以前にも『ロシ 了の女性』(1995 年)，『ソ連の女性』(1975，1990，1991 年）などの統計資料集が出版されているが, 雇用については一部の経済部門または職種の男女比が揭載されている程度である。国家統計委員会が 「ジェンダー統計指標システム」を作成したのは 1998 年であり，1998 年についても若干の資料はある ものの, 多くのデータは 1999 年以降のみである。Белоконная Л., «Гендерная статистика в России», Вопросы экономики, 2000, № 3, стр. 110-121. 